\title{
FERC $V$. EPSA AND THE PATH TO \\ A CLEANER ELECTRICITY SECTOR
}

\author{
INTRODUCTION
}

Joel B. Eisen *

\section{$\mathrm{I}$}

$\mathrm{t}$ is no stretch to call Federal Energy Regulatory Commission v. Electric Power Supply Ass'n ("EPSA") ${ }^{1}$ the most significant Supreme Court decision involving the modern electric grid since the 2002 decision in New York v. FERC validated the Federal Energy Regulatory Commission ("FERC") rule that undergirds modern wholesale electricity markets. ${ }^{2}$ This January, in a 6-2 decision authored by Justice Elena Kagan, the Court held that FERC has authority over "demand response" ("DR")—-bids of reductions in electricity consumption into wholesale markets ${ }^{3}$ - under the Federal Power Act ("FPA"). ${ }^{4}$ The Court also held that FERC's formula for compensating DR at the same wholesale market price paid to generators in the energy markets administered by regional grid operators known as independent system operators ("ISOs") and regional transmission organizations ("RTOs") $)^{5}$ was not arbitrary

\footnotetext{
" Professor of Law and Austin Owen Research Fellow, University of Richmond School of Law. The author thanks Emily Hammond for her insights and the Harvard Environmental Law Review for the kind invitation to participate in this special issue.

${ }^{1} 136$ S. Ct. 760 (2016).

${ }^{2}$ New York v. FERC, 535 U.S. 1, 1019-20, 1028 (2002). The New York decision upheld core provisions of FERC's Order No. 888. Promoting Wholesale Competition Through Open Access Non-Discriminatory Transmission Services by Public Utilities; Recovery of Stranded Costs by Public Utilities and Transmitting Utilities, 61 Fed. Reg. 21,540 (May 10, 1996) (codified at 18 C.F.R. § 35,385).

${ }^{3}$ FERC defines "demand response" as "a reduction in the consumption of electric energy by customers from their expected consumption in response to an increase in the price of electric energy or to incentive payments designed to induce lower consumption of electric energy." 18 C.F.R. $\S$ 35.28(b)(4) (2015); Joel B. Eisen, Who Regulates the Smart Grid? FERC's Authority over Demand Response Compensation in Wholesale Electricity Markets, 4 SAN DiEGO J. ClimATE \& Energy L. 69, 70 (2013) [hereinafter Eisen, Who Regulates the Smart Grid?] (describing the various forms of DR).

${ }^{4}$ EPSA, 136 S. Ct. at 765, 784. Five Justices joined Justice Kagan's majority opinion, with Justices Scalia and Thomas dissenting. (Justice Alito recused himself from the case.)

${ }^{5}$ Today, seven regional grid operators-ISOs and RTOs-manage transmission and oversee wholesale power markets. See FERC, ElECTRIC MARKET OvERviEW (2012), https://perma.cc/729F-G46R; The Role of ISOs and RTOs, ISO/RTO COUNCIL, https://perma.cc/6RXA-F7VZ; Regional Transmission Organizations, Order No. 2000, 65 Fed. Reg. 12,088 (Jan. 6, 2000) (encouraging RTOs' formation and set forth requirements for qualifying to be an RTO); Order No. 888, 61 Fed. Reg. at 21,595-96 (establishing requirements for ISOs); Joel B. Eisen, Regulatory Linearity, Commerce Clause Brinksmanship, and Retrenchment in
} 
and capricious. In reaching these conclusions, the Court reversed a decision of the D.C. Circuit Court of Appeals that had invalidated FERC's second major DR rule, ${ }^{6}$ Order $745 .{ }^{7}$

EPSA capped more than a decade of activity aimed at promoting DR in wholesale electricity markets. ${ }^{8}$ Today, these markets provide power that serves two-thirds of the nation's electricity load. ${ }^{9}$ FERC sees enormous potential for DR in these markets as a tool for reducing electricity consumption and thereby balancing supply and demand and reducing costs to consumers, ${ }^{10}$ improving reliability, ${ }^{11}$ and achieving environmental benefits. ${ }^{12}$ Because there had been

Electric Utility Deregulation, 40 WAKE FOREST L. REV. 545, 551-52 (2005) (describing requirements for ISOs and RTOs); Emily Hammond \& David B. Spence, The Regulatory Contract in the Marketplace, 69 VAND. L. REV. 141, 149-57 (2016) (describing the evolution of modern wholesale power markets and their operation). The difference between "ISO" and "RTO" is unimportant to the analysis in this Introduction. Cf. Hammond and Spence, supra, at 153 n.56 (reaching the same conclusion for a discussion of grid reliability).

ISOs and RTOs manage energy, capacity, and ancillary services markets, with the first of these at issue in EPSA. Energy markets trade power through bids that establish market clearing prices. Id. at 154. Ancillary services markets trade reserves (generation not currently used but available to serve load) and other services such as "regulation" (services necessary to keep grid frequency in balance). Id. at 153. Forward capacity markets, at issue in the Supreme Court this spring in Hughes v. Talen Energy Marketing, PPL Energyplus, LLC v. Nazarian, 753 F.3d 467 (4th Cir. 2014), cert. granted sub nom. Hughes v. Talen Energy Mktg., 136 S. Ct. 382 (Oct. 19, 2015) (No. 14-614), aim for resource adequacy by providing incentives to ensure sufficient generating capacity in the region to meet projected future demand. See infra notes 63-66.

${ }^{6}$ EPSA v. FERC, 753 F.3d 216, 225 (D.C. Cir. 2014), overruled by EPSA, 136 S. Ct. at 773.

${ }^{7}$ Demand Response Compensation in Organized Wholesale Energy Markets, Order No. 745, 134 FERC \ 61,187 (2011) (codified at 18 C.F.R. § 35).

${ }^{8}$ The Court described the introduction of DR into wholesale markets in the early 2000s. EPSA, 136 S. Ct. at 770. DR itself is nothing new, as it dates to "curtailment" and "peak shaving" programs of the 1980s and 1990s. Jon Wellinghoff \& David E. Morenoff, Recognizing the Importance of Demand Response: The Second Half of the Wholesale Electric Market Equation, 28 ENERGY L.J. 389, 394 (2007).

9 FERC, Electric Power Markets: National Overview, FERC (2016), https://perma.cc/ 3GNA-JPJ9.

${ }^{10}$ Owen Comstock, Demand Response Saves Electricity During Times of High Demand, U.S. ENERGY INFO. ADMIN. (Feb. 8, 2016), https://perma.cc/BMP8-6CDA (discussing DR's role during times of peak demand to reduce stress on the electric grid, and showing peak demand savings of 12,700 MW in 2014); FERC v. EPSA, 136 S. Ct. at 770 (citing a 2007 study showing that "a demand response program reducing electricity usage by $3 \%$ in peak hours would lead to price declines of $6 \%$ to $12 \% ”)$.

For one particularly significant example of DR's role in to reducing grid stress, see FERC, Assessment OF DEMAND Response \& AdVAnced MEtering 11-13 (2014), https://perma.cc/F6MH-D2PE, which discussed DR's important role in meeting the "numerous challenges for electricity system operators" during the extremely cold winter of 2013-2014.

${ }^{11}$ Joel B. Eisen, Distributed Energy Resources, "Virtual Power Plants," and the Smart Grid, 7 HOUSTON ENVTL. \& ENERGY L. \& POL'Y J. 191, 203 (2012) (discussing DR's role in providing regulation in ancillary services markets and thereby improving reliability by balancing intermittent resources such as solar and wind). 
little DR participation, however, the Energy Policy Act of 2005 stated Congress' policy that "unnecessary barriers to demand response participation in energy, capacity and ancillary service markets shall be eliminated." ${ }^{13}$ Three years later, FERC issued Order 719. ${ }^{14}$ That rule required ISOs and RTOs to revise their tariffs and allow DR aggregators (firms that bundle demand reductions and bid them into wholesale energy markets ${ }^{15}$ to participate in wholesale markets. ${ }^{16}$ Order 719 required ISOs and RTOs to permit aggregators to bid DR on behalf of retail customers directly into the wholesale markets, except where a state's laws prevented it. ${ }^{17}$ Yet barriers to entry continued to hamper DR's growth. ${ }^{18}$

To address this situation, FERC issued Order 745 in $2011 .{ }^{19}$ It aimed to address "concerns that current compensation levels inhibited meaningful demand-side participation" in wholesale markets. ${ }^{20}$ It required ISOs and RTOs

\footnotetext{
${ }^{12}$ By reducing peak demand, DR may reduce emissions from existing power plants and help avoid "unnecessary expenses of building new generation, transmission, and distribution infrastructure" and the pollution associated with it. Joel B. Eisen, Smart Regulation and Federalism for the Smart Grid, 37 HARV. EnVTL. L. REV. 1, 12 (2013) [hereinafter Eisen, Smart Regulation and Federalism for the Smart Grid].

The extent to which DR leads to emissions reductions has been debated. If customers reduce purchases from wholesale markets, but substitute polluting sources "behind the meter" such as diesel back-up generators, the emissions reductions would be less substantial. See Del. Dep't of Nat. Res. \& Envtl. Control v. EPA, 785 F.3d 1 (D.C. Cir. 2015) (rejecting EPA's "Reciprocating Internal Combustion Engines" emissions standards that allowed back-up diesel generators to operate more often to promote DR); cf. U.S. DEP'T OF ENERGY, BENEFITS OF DEMAND RESPONSE IN ELECTRICITY MARKETS AND RECOMMENDATIONS FOR ACHIEVING THEM 29 (2006), https://perma.cc/ZC9M-8J8X (noting emissions reductions as a potential benefit but cautioning that emissions reductions are "dependent on the emissions profiles and marginal operating costs of the generation plants in specific regions").

${ }^{13}$ Energy Policy Act of 2005, Pub. L. 109-58, § 1252(f), 119 Stat. 966 (2005).

${ }^{14}$ Wholesale Competition in Regions with Organized Electric Markets, Order No. 719, 73 Fed. Reg. 64,100-01 (Oct. 28, 2008).

${ }^{15}$ Aggregators, or "curtailment service providers," bundle demand reductions and bid them into wholesale markets. Order 745, 134 FERC \ 61,187 para. 19; 18 C.F.R. § 35.28(g)(1)(iii) (2015) (requiring ISOs and RTOs to receive bids from aggregators). This facilitates market entry by those customers precluded from trading on wholesale markets under RTOs' market rules that require bidders to offer a minimum amount of energy. Eisen, Who Regulates the Smart Grid?, supra note 3 , at 81 .

${ }^{16}$ Order No. 719, 73 Fed. Reg. at 64,101.

${ }^{17} 18$ C.F.R. $\$ 35.28(\mathrm{~g})(1)(\mathrm{i})$.

${ }^{18}$ Peter Cappers, Jason MacDonald \& Charles Goldman, LaWrence Berkeley NAT'L LAB., MARKET AND POLICY BARRIERS FOR DEMAND RESPONSE PROVIDING ANCILLARY SERVICES IN U.S. ELECTRICITY MARKETS 3 (2013) (discussing barriers to aggregator participation in ancillary services markets and citing studies by FERC and others about barriers to DR aggregator participation in wholesale markets).

${ }^{19}$ Order 745, 134 FERC $961,187$.

${ }^{20}$ Id. para. 1.
} 
to compensate DR bid by aggregators in wholesale energy markets at the prevailing market price received by generators, assuming DR resources "have the capability to balance supply and demand and when payment of the market price for energy to these resources is cost-effective as determined by a net benefits test." ${ }^{21}$ FERC justified Order 745 under two FPA provisions: Section $205,{ }^{22}$ giving it authority to decide just and reasonable rates, and Section $206,{ }^{23}$ giving it the power to remedy discriminatory practices affecting wholesale rates.

The Electric Power Supply Association ("EPSA", the trade association for generators in competitive markets) and other challengers opposed Order 745. They succeeded in the D.C. Circuit, where a divided three-judge panel held that Order 745 was "ultra vires agency action." ${ }^{24}$ In the court's view, DR was solely a retail-level activity and therefore the exclusive province of the states, FERC had no authority over it, and, moreover, giving FERC jurisdiction over DR would have no boundaries. ${ }^{25}$ Summoning a parade of horribles, the court believed that if Order 745 stood, FERC could extend its regulatory reach deep into the economy, even regulating the steel and labor markets if it so chose. ${ }^{26}$ The decision threw DR's future into chaos. ${ }^{27}$

\footnotetext{
${ }^{21} 18$ C.F.R. $\S 35.28(\mathrm{~g})(1)(\mathrm{v})$.

22 16 U.S.C. $\S 824 \mathrm{~d}(2012)$.

${ }^{23}$ Section 206 empowers FERC to remedy a practice it finds "unjust" or "unreasonable": if "any rule, regulation, practice, or contract affecting such rate, charge, or classification is unjust, unreasonable, unduly discriminatory or preferential," FERC must "determine the just and reasonable rate, charge, classification, rule, regulation, practice, or contract to be thereafter observed and in force, and shall fix the same by order." 16 U.S.C. § 824e (2012). The discrimination, in the case of DR, was the compensation scheme that precluded it from taking part meaningfully in the markets.
}

${ }^{24}$ EPSA v. FERC, 753 F.3d 216, 225 (D.C. Cir. 2014).

${ }^{25} \mathrm{Id}$. at 221-22. The D.C. Circuit also rejected the pricing formula itself as arbitrary and capricious. Id. at 225 .

${ }^{26} I d$. at 221.

${ }^{27}$ The D.C. Circuit's decision only invalidated DR bids into energy markets. Yet because it held that FERC lacked authority over DR, it jeopardized DR's status in all wholesale markets. On the same day as the decision was issued, FirstEnergy Corp. filed a complaint asking FERC to extend its reach, bar DR bids into the PJM RTO's capacity market, and order PJM to recalculate the results (without DR) of its most recent capacity auction. Complaint of FirstEnergy Service Co. at 1-2, FirstEnergy Serv. Co. v. PJM Interconnection, LLC (FERC 2014) (No. EL14-55-000). Over the next eighteen months, the result was a series of stopgap and transitional proposals designed to adapt to the decision, leaving the ultimate fate of DR in markets up in the air. Robert Walton, Uncertainty Is the New Constant for Demand Response Markets, UTILITY DivE (Apr. 8, 2015), https://perma.cc/M3ND-SWY3.

Uncertainty extended to how DR might be conducted as an exclusively state-level matter. PETER CAPPERS \& ANDY SATCHWEll, LAWRENCE BERKELEy NAT'L LAB., CONSIDERATIONS FOR STATE REgULATORS AND POLICYMAKERS IN A POST-FERC ORDER 745 WORLD (2015), https://perma.cc/TZ5R-UUSN (pre-EPSA analysis explaining in detail, with references to individual states' situations, how DR programs might be administered in the absence of FERC authority over them). 
Reversing the D.C. Circuit, the Supreme Court held that the FPA's "plain terms" gave FERC authority to regulate DR in wholesale markets. ${ }^{28}$ Under the FPA, FERC's authority extends to "the transmission of electric energy in interstate commerce" and "the sale of electric energy at wholesale in interstate commerce." 29 This gives it authority, the Court stated, to regulate "both wholesale rates and the panoply of rules and practices affecting them." ${ }^{30}$ Construing FPA Section 206, the Court stated that FERC has authority over discriminatory "practices" that "directly affect" wholesale rates. ${ }^{31}$ Interpreting the term "practices," the Court stated, "As we have explained in addressing similar terms like 'relating to' or 'in connection with,' a non-hyperliteral reading is needed to prevent the statute from assuming near-infinite breadth." ${ }^{2} 2$ The Court relied on case precedent limiting FERC's broad authority. Citing a D.C. Circuit case involving California's grid operator, ${ }^{33}$ the Court found that, "under a commonsense construction of the FPA's language," FERC's jurisdiction is limited "to rules or practices that 'directly affect the [wholesale] rate." 34 The Court rejected claims by Order 745's opponents that this construction expanded FERC's jurisdiction too broadly. ${ }^{35}$

Justice Kagan stated that Order 745 satisfied the "directly affecting" standard "with room to spare," ${ }^{36}$ observing that "market operators' payments for demand response commitments" are practices that "directly affect wholesale rates." ${ }^{37}$ The Court's explanation was straightforward and compelling: "Wholesale demand response, in short, is all about reducing wholesale rates; so too, then, the rules and practices that determine how those programs operate." 38 Moreover, the Court found that to hold otherwise would "conflict with the

\footnotetext{
${ }^{28}$ FERC v. EPSA, 136 S. Ct. 760, 773 (2016).

${ }^{29} 16$ U.S.C. § 824(b)(1) (2012). As EPSA acknowledged, the FPA closed the "Attleboro gap" and created a clear split between state and federal authority. EPSA, $136 \mathrm{~S}$. Ct. at 767 (citing Pub. Util. Comm'n of R.I. v. Attleboro Steam \& Elec. Co., 273 U.S. 83, 90 (1927)).

${ }^{30}$ EPSA, 136 S. Ct. at 773 .

${ }^{31} I d$. at $773-74$.

${ }^{32} I d$. at 774 .

${ }^{33}$ Cal. Indep. Sys. Op. Corp. v. FERC, 372 F.3d 395 (D.C. Cir. 2004); Joel B. Eisen, FERC's Expansive Authority to Transform the Electric Grid, 49 U.C. DAVIS L. REV. (forthcoming 2016) [hereinafter Eisen, FERC's Expansive Authority to Transform the Electric Grid] (discussing CAISO's application to limiting a "directly affecting" standard); Eisen, Who Regulates the Smart Grid?, supra note 3, at 91-92 (discussing CAISO's importance in empowering FERC to regulate practices affecting wholesale rates).

${ }^{34}$ EPSA, 136 S. Ct. at 774 (citing Cal. Indep. Sys. Operator Corp., 372 F.3d at 403).

${ }^{35} I d$. at 774 .

${ }^{36} I d$.

${ }^{37} I d$.

${ }^{38} I d$.
} 
Act's core purposes by preventing all use of a tool that no one (not even EPSA) disputes will curb prices and enhance reliability in the wholesale electricity market." 39

The "directly affecting" standard, and the Court's application of it to DR, rest on a cogently articulated interpretation of the FPA. ${ }^{40} \mathrm{It}$ is consistent with the analysis in the amicus brief that the author and three co-authors filed with the Court on behalf of twenty-five energy law scholars. ${ }^{41}$ And, a historical analysis of the "practices affecting rates" language demonstrates that it has been interpreted broadly and flexibly in the context of the FPA and other regulatory statutes since the early 1900s, and that in the specific setting of the electric grid, the "directly affecting" test is the logical culmination of developments that have been decades in the making. ${ }^{42}$

In granting FERC this broad authority, the Court rejected an argument that had swayed the D.C. Circuit: that FERC was impermissibly regulating retail sales, authority over which is allocated to the states under the FPA. ${ }^{43} \mathrm{As}$ the Court noted, "a FERC regulation does not run afoul of [the FPA's] proscription just because it affects-even substantially-the quantity or terms of retail sales. . . . To the contrary, transactions that occur on the wholesale market have natural consequences at the retail level. And so too, of necessity, will FERC's regulation of those wholesale matters." ${ }^{\prime 4}$ When FERC regulates the wholesale markets, the Court concluded, "then no matter the effect on retail rates," ${ }^{45}$ the FPA does not preclude FERC from regulating. And, the Court stated, "in setting rules for demand response, that is all FERC has

\footnotetext{
${ }^{39} I d$. at 773 .

${ }^{40}$ The Court's confirmation of FERC's authority over DR is supported by literature on Order 745 that demonstrate that the Commission had this authority, notwithstanding its opponents' claims. Eisen, FERC's Expansive Authority to Transform the Electric Grid, supra note 33; Eisen, Who Regulates the Smart Grid?, supra note 3, at 90-92; cf. Richard J. Pierce, Jr., A Primer on Demand Response and a Critique of FERC Order 745, GEO. WASH. J. ENERGY \& ENVTL. L. 102, 108 (2012) (expressing concerns about Order 745 but nonetheless suggesting that it should survive judicial review).

${ }^{41}$ Amicus Curiae Brief of Energy Law Scholars in Support of Petitioners, FERC v. EPSA, 136 S. Ct. 760 (2016) (No. 14-840) (urging the Court to find that FERC had jurisdiction over DR bid into the organized wholesale markets under the FPA's "practices affecting rates" provision, and suggesting that it adopt the "directly affecting" limitation expressed in CAISO).

${ }^{42}$ Eisen, FERC's Expansive Authority to Transform the Electric Grid, supra note 33 (discussing the history of the "practices affecting rates" provision, concluding that the Court properly found that it conferred on FERC authority over DR, and outlining four guidelines for courts and FERC for deciding which matters FERC properly regulates and which are left to the states).
}

${ }^{43}$ EPSA v. FERC, 753 F.3d 216, 223 (D.C. Cir. 2014).

${ }^{44}$ See EPSA, 136 S. Ct. at 776.

${ }^{45}$ Id. 
done." ${ }^{46}$ Citing ONEOK v. Learjet, ${ }^{47}$ its most recent decision on FERC's authority, Justice Kagan observed that, "the Commission's justifications for regulating demand response are all about, and only about, improving the wholesale market." ${ }^{48}$

Finally, the Court rejected an argument that paying DR providers market prices gives them a "windfall-a kind of 'double-payment'-unless market operators subtract the savings associated with conserving electricity from the ordinary compensation level." ${ }^{49}$ The Court found that in setting this compensation formula, the "Commission engaged in reasoned decisionmaking-that it weighed competing views, selected a compensation formula with adequate support in the record, and intelligibly explained the reasons for making that choice. ${ }^{50}$

\section{FERC $V$. EPSA IS A LANDMARK DECISION, AND ITS SIGNIFICANCE CANNOT BE UNDERSTATED}

First, the Court made a definitive pronouncement on FERC's authority over end users of electricity who also provide resources back to the electric grid. ${ }^{51}$ The "directly affecting" standard now governs how these customers participate in the wholesale markets. That will have immediate implications for DR's future in the markets, with specific short-term impacts on DR programs that ISOs and RTOs have either underway or on the drawing board. ${ }^{52}$ In the long run, this concise, broad jurisdictional standard gives FERC considerable

\section{${ }^{46} I d$.}

${ }^{47}$ ONEOK, Inc. v. Learjet, Inc., 135 S. Ct. 1591 (2015); see also Emily Hammond, Energy Law's Jurisdictional Boundaries: A Call for Course Correction, GEO. WASH. L. REV. DOCKET (April 28, 2014), https://perma.cc/46AC-XXBP [hereinafter Hammond, Energy Law's Jurisdictional Boundaries: A Call for Course Correction] (discussing the ONEOK decision).

${ }^{48}$ EPSA, 136 S. Ct. at 776-77 (citing ONEOK, Inc., 135 S. Ct. at 1599).

${ }^{49} I d$. at 782; cf. Pierce, supra note 40, at 108 (opposing the pricing scheme but concluding that the net benefits test alleviated his concerns by limiting the likely amount of overcompensation).

${ }^{50}$ EPSA, 136 S. Ct. at 782; Emily Hammond, Deference for Interesting Times, 28 GEO. ENVTL. L. REV. (forthcoming 2016) (manuscript on file with author) (stating that EPSA's analysis of the pricing issue "illustrates the best of [State Farm] hard-look review for its detailed explanation and careful look at the agency's reasoning").

${ }^{51}$ See generally Sharon Jacobs, Consumer Generation, ECOL. L.Q. (forthcoming 2016) (discussing challenges to managing "prosumers" on the electric grid).

${ }^{52}$ David T. Doot et al., What's Next for Wholesale Electricity Market Operators, LAW360 (Feb. 11, 2016), https://perma.cc/E2WS-MQVJ (discussing the impacts of EPSA on current DR docket proceedings in the PJM Interconnection LLC, ISO-New England, Midcontinent ISO, New York ISO, and California ISO). The first two of these RTOs will see considerable change, because their DR programs were thrown into uncertainty after the D.C. Circuit's decision. See id. 
flexibility to promote a cleaner, more efficient Smart Grid. ${ }^{53}$ FERC has ample authority over the electric grid, so long as its initiatives may be construed as "practices" that "directly affect" wholesale electricity rates. This opens up a vast new frontier for FERC to innovate and pursue broad policy goals-such as promoting clean and renewable energy - in the wholesale markets, as long as the core "directly affecting" standard is met. As one analysis has demonstrated, FERC could justify a (hypothetical) carbon price in the wholesale markets under this standard..$^{54}$

EPSA's treatment of the split between federal and state jurisdiction over the electric grid is also noteworthy. The Court concluded that FERC's authority in the wholesale markets over DR is not exclusive and must coexist with state jurisdiction. Indeed, EPSA features "notable solicitude" for the states' historical role in electricity regulation..$^{55}$ Under Orders 719 and 745 , states can also exercise control over DR aggregators. They can prohibit consumers from bidding DR into wholesale markets, license aggregators and conduct any DR programs that do not involve bidding into the wholesale markets. Finally, because states set retail rates, they can "insulate them from price fluctuations in the wholesale market." ${ }^{15}$

This analysis heralds a new era of allocating jurisdictional responsibility over the electric grid. It recognizes that both FERC and the states can simultaneously take actions impacting the wholesale markets, and therefore contemplates concurrent regulatory jurisdiction. ${ }^{57}$ This might appear to be a break from the jurisdictional dividing line that has characterized electricity regulation since the FPA's enactment in 1935. Under that well-known standard, as noted above, federal jurisdiction extends to wholesale transactions and the states retain jurisdiction over retail sales. ${ }^{58}$ However, as the Court has now noted, ${ }^{59}$ reflecting the views of many other observers, ${ }^{60}$ this bright line jurisdictional split is unworkable in the modern, interconnected electric grid.

\footnotetext{
${ }^{53}$ For a discussion of the Smart Grid's opportunities and challenges, see Eisen, Smart Regulation and Federalism for the Smart Grid, supra note 12.

${ }^{54}$ Eisen, FERC's Expansive Authority to Transform the Electric Grid, supra note 33, at 38-45.

${ }^{55}$ EPSA, 136 S. Ct. at 779.

${ }^{56} I d$. at 777.

${ }^{57}$ See generally Jim Rossi, The Brave New Path of Energy Federalism, 95 TEX. L. REV. (forthcoming 2016).

${ }^{58}$ EPSA, 136 S. Ct. at 768.

${ }^{59} I d$.

${ }^{60}$ See, e.g., Eisen, FERC's Expansive Authority to Transform the Electric Grid, supra note 33, at 6-7; Rossi, supra note 57; Robert R. Nordhaus, The Hazy "Bright Line": Defining Federal and State Regulation of Today's Electric Grid, 36 ENERGY L.J. 203 (2015); Sharon Jacobs, Bypassing Federalism and the Administrative Law of Negawatts, 100 IOWA L. REV. 885, 941 (2015) ("[T] he
} 
EPSA eschews this last remnant of the bygone era of "dual federalism" 11 that treated federal and state jurisdiction formalistically as separate and distinct spheres of authority. Instead, it recognizes that state and federal authority over the electric grid must be construed as overlapping. This has enormous implications going forward. Working with the "directly affecting" test may yield a clearer picture of state and federal concurrent jurisdiction, preserving room for each level of government to craft policies for integrating clean and renewable energy into the electric grid, reducing greenhouse gas emissions and achieving other goals. ${ }^{62}$

However, this new approach leaves many questions unanswered. One issue not addressed in EPSA is how far states can go in electricity regulation if their laws impact wholesale markets. This spring, the Court will test this proposition-and therefore, the "directly affecting" test's contours-in Hughes v. Talen Energy Marketing. ${ }^{63}$ Hughes involves Maryland's law that provided incentives for a new power plant to locate in the state. Maryland state officials believed the price signals produced by the PJM capacity market were not leading to construction of enough new power plants in the state. To prompt building of a new plant, the law offered a subsidy above the market clearing price. FERC claimed this interfered with pricing in the wholesale markets, and the Fourth Circuit Court of Appeals agreed. ${ }^{64}$ It found that field preemption applied, concluding the scheme of federal regulation of wholesale markets is so all-encompassing that it leaves no room for the state law. ${ }^{65}$

EPSA upheld FERC's authority generally over DR, and because it did not evaluate a specific state law's impacts on wholesale markets, the preemption

federalism boundaries drawn in 1935 in the Federal Power Act may no longer be appropriate in today's world."); Hannah J. Wiseman, Moving Past Dual Federalism to Advance Electric Grid Neutrality, 100 IOWA L. ReV. BuLl. 97, 99 (2015).

${ }^{61}$ Wiseman, supra note 60, at 97; see also Ernest A. Young, Dual Federalism, Concurrent Jurisdiction, and the Foreign Affairs Exemption, 69 GEO. WASH. L. REV. 139, 139 (2001) (describing the "death" of dual federalism generally).

${ }^{62}$ See generally Eisen, FERC's Expansive Authority to Transform the Electric Grid, supra note 33, and accompanying text (discussing a hypothetical carbon adder in the wholesale markets).

${ }^{63}$ PPL EnergyPlus, LLC v. Nazarian, 753 F.3d 467 (4th Cir. 2014), cert. granted sub nom. Hughes v. Talen Energy Mktg., 136 S. Ct. 382 (Oct. 19, 2015) (No. 14-614). The speed with which the Court is acting to clarify jurisdictional issues left open after EPSA is itself unusual. Ari Peskoe, Electricity Regulation Is Back at the Supreme Court, Again, THE ENERGY Collective (Feb. 18, 2016), https://perma.cc/M4NZ-JZ93 ("It is highly unusual for the Supreme Court to decide two cases about electricity regulation in a single term.").

${ }^{64}$ See generally Nazarian, 753 F.3d at 467 . The Third Circuit struck down a similar New Jersey law, and while the Court did not accept that case for review, the decision in Hughes is widely expected to impact the New Jersey law, due to the similarity between the two states' laws. PPL EnergyPlus, LLC v. Solomon, 766 F.3d 241 (3d Cir. 2014).

${ }^{65}$ Nazarian, 753 F.3d at 476. 
issue did not arise. At oral argument in Hughes, the Justices appeared ready to uphold the Fourth Circuit. ${ }^{66}$ The Court can be expected to reiterate FERC's sole authority over wholesale rates, and may use principles of conflict preemption (instead of field preemption) to decide that Maryland's law conflicts with the FPA and cannot stand because it directly changes the amount a power plant owner receives from the wholesale markets. This would also be warranted under EPSA. Setting rules for capacity market auctions is an obvious example of a "practice" that "directly affects" wholesale rates.

Yet the states' authority over power plants is also unquestioned. States may select the types, sizes, and sites of power plants to be built in the state. Using conflict preemption principles might leave room for other state incentives to promote power plant development, as long as the state does not interfere directly with wholesale rates. ${ }^{67} \mathrm{~A}$ clue to how the Court may set the boundaries between federal and state jurisdiction comes from the test it enunciated in $O N E O K$, under which a state law is preempted if it is "aimed directly at interstate purchasers and wholesales for resale. ${ }^{68}$ But the challenge of striking the jurisdictional balance accurately in Hughes shows the work begun in EPSA is hardly complete.

Finally, EPSA is significant as a signal of the Court's approach to statutory interpretation. On the issue of FERC's authority over DR, one might have expected the Court to conduct a Chevron ${ }^{69}$ analysis. Recently, the Court concluded that agencies are accorded Chevron deference when they are delineating the extent of their jurisdiction. ${ }^{70}$ The Court could have found the statutory term "practices" or "affect" to be ambiguous, and then deferred to FERC's permissible construction in Order 745. Because the Court found that

${ }^{66}$ See generally Transcript of Oral Argument, Hughes v. Talen Energy Mktg., 136 S. Ct. 382 (Oct. 19, 2015) (No. 14-614).

${ }^{67}$ As the Solicitor General mentioned in an amicus brief in Hughes, one example would be favorable tax policies for power plant development. Brief For the United States as Amicus Curiae at 19, Hughes v. Talen Energy Mktg., 136 S. Ct. 382 (Oct. 19, 2015) (No. 14-614). The Court would be more likely to view this as comparable to state antitrust law (at issue in $O N E O K$ ) that applies broadly to a number of industries, and less likely to invalidate it as taking "direct aim" at the wholesale markets. Id. at 22.

${ }^{68}$ ONEOK, Inc. v. Learjet, Inc., 135 S. Ct. 1591, 1599-1600 (2015); see also Hammond, Energy Law's Jurisdictional Boundaries: A Call for Course Correction, supra note 47 (discussing potential applications of this test).

${ }^{69}$ See generally Chevron U.S.A. Inc. v. Nat. Res. Def. Council, Inc., 467 U.S. 837 (1984); see also Eisen, Who Regulates the Smart Grid?, supra note 3, at 74 (arguing that Order 745 was supportable under Chevron).

${ }^{70}$ City of Arlington v. FCC, 133 S. Ct. 1863 (2013); Hammond, Deference for Interesting Times, supra note 50 , at 4 (noting that "agencies' jurisdictional interpretations are also awarded Chevron deference"). 
Order 745 "complies with the FPA's plain terms," 71 however, it grounded its holding in the statutory text and explicitly stated that it was not addressing FERC's claim that it was entitled to Chevron deference. ${ }^{72}$ This makes EPSA all the more important because the Court's construction of the FPA makes it difficult for future Commissions to alter or reverse this finding. ${ }^{73}$

Putting this all together, EPSA's importance is evident. It highlights how an eighty-year-old statute can be retooled for the modern era $^{74}$ and yet retain consistency with a body of law spanning over more than 100 years. ${ }^{75}$ FERC's ability to control "practices" on an industry-wide basis, with appropriate limits set by the Court, may have far-reaching consequences almost unimaginable today. Consider the analogy of the modern telecommunications industry. ${ }^{76} \mathrm{~A}$ 1956 decision - Hush-A-Phone ${ }^{77}$ —allowed phone customers to attach a plastic device to a phone to reduce the risk of overhearing a phone call, ${ }^{78}$ and the 1968 FCC Carterfone ${ }^{79}$ ruling invalidated AT\&T's prohibition of a device that manually connected private two-way radio systems to the telephone network. ${ }^{80}$

\footnotetext{
${ }^{71}$ FERC v. EPSA, 136 S. Ct. 760,773 (2016).
}

${ }^{72}$ Id. at 773 n.5 ("Because we think FERC's authority clear, we need not address the Government's alternative contention that FERC's interpretation of the statute is entitled to deference under Chevron U.S.A. Inc. v. Natural Resources Defense Council, Inc., 467 U. S. 837 (1984).”); see also Emily Hammond, Energy Law's Jurisdictional Boundaries: Staying the Course, GEO. WASH. L. REV. DOCKET (Jan. 30, 2016), https://perma.cc/MR4G-UZCN (discussing EPSA as part of a "trend toward more traditional, pre-Chevron approaches to interpreting regulatory statutes").

${ }^{73}$ Hammond, Deference for Interesting Times, supra note 50, at 4 (noting that under Brand $X$, if an agency's construction of its own jurisdiction was accorded Chevron deference, "this means that an agency could also change its view of its jurisdictional authority provided the statute is ambiguous").

${ }^{74}$ For a general discussion of this challenge, see Jody Freeman \& David B. Spence, Old Statutes, New Problems, 163 U. PA. L. REV. 1 (2014).

75 See generally Eisen, FERC's Expansive Authority to Transform the Electric Grid, supra note 33.

${ }^{76}$ This analogy is explored in Joel B. Eisen, An Open Access Distribution Tariff: Removing Barriers to Innovation on the Smart Grid, 61 UCLA L. Rev. 1712 (2014) [hereinafter Eisen, An Open Access Distribution Tariff].

${ }^{77}$ Id. at 1743 n.161 (citing Hush-A-Phone Corp. v. United States, 238 F.2d 266 (D.C. Cir. 1956)).

${ }^{78}$ Hush-A-Phone involved the "practices affecting rates" provision of the Communications Act of 1934, worded similarly to the FPA's provision. In that case, the D.C. Circuit rejected the argument by the monopoly company-AT\&T - that claimed the statutory provision gave it the right to "forbid attachment to the telephone of any device "not furnished by the telephone company." Hush-A-Phone Corp., 238 F.2d at 267, 269. The D.C. Circuit established a principle that prohibiting a customer's "foreign attachment" (the Hush-A-Phone was a plastic device designed to fit over the ear and reduce background interference with phone calls) was "in unwarranted interference with the telephone subscriber's right reasonably to use his telephone in ways which are privately beneficial without being publicly detrimental." Id. at 269; see also Eisen, An Open Access Distribution Tariff, supra note 76, at 1744 n.162.

${ }^{79}$ In re Carterfone Device in Message Toll Tel. Serv., 13 F.C.C.2d 420 (1968).

${ }^{80}$ Id.; see also Eisen, An Open Access Distribution Tariff, supra note 76, at 1744 n.163. 
These decisions established fundamental principles that enabled the connection of much more sophisticated equipment to communications networks. Without Hush-A-Phone and Carterfone there would have been no answering machines, fax machines, and no modems connected without telephone company interference. So, without these decisions-both of which attracted little public recognition at the time- - there would be no consumer use of the Internet. ${ }^{81}$

Is EPSA the electric grid's Hush-A-Phone or Carterfone? Time will tell. For now, FERC has authority over practices "directly affecting" wholesale rates, and Order 745's core requirement has been upheld: when DR is bid into the wholesale markets, it must be compensated at the same level that generators receive. ${ }^{82}$ Still, as noted above, there are significant issues remaining with respect to EPSA's scope.

The Symposium begins with two Essays that focus on EPSA's implications for states and their clean energy policy goals. In The Essential Role of State Engagement in Demand Response, Maryland Public Service Commissioner Anne Hoskins and Rhode Island Public Utilities Commissioner Paul Roberti discuss EPSA's potential impacts on their respective states (and others), including the interplay with each state's respective RTO, and discuss the extent to which the decision improves the potential for cooperative electricity federalism. ${ }^{83}$ In FERC v. EPSA and Adjacent State Regulation of Customer Energy Resources, Professor Jim Rossi and former FERC Chairman Jon Wellinghoff explore the decision's impact on states' clean energy initiatives and posit that the decision gives states flexibility while ensuring that their policies complement federal programs. ${ }^{84}$

The next two essays advance approaches for fostering grid-edge innovation in the aftermath of EPSA. In Balancing on the Grid Edge: Regulating for Economic Efficiency in the Wake of FERC v. EPSA, Denise A. Grab explains why it is optimal to allow all regulators who are making policy decisions involving technologies at the grid edge to consider both the demand- and supply-side effects of their decisions, ideally through a comprehensive benefit-cost analy-

\footnotetext{
${ }^{81}$ See Eisen, An Open Access Distribution Tariff, supra note 76, at 1744 n.167 (quoting Jason Oxman, The FCC and the Unregulation of the Internet 15 (FCC Office of Plans \& Policy, Working Paper No. 31, 1999), https://perma.cc/K75D-ZJWC.

${ }^{82}$ FERC v. EPSA, 136 S. Ct. 760, 784 (2016).

${ }^{83}$ Anne Hoskins \& Paul Roberti, The Essential Role of State Engagement in Demand Response, 40 HARV. ENVTL. L. REV. F. 14 (2016).

${ }^{84}$ Jim Rossi \& Jon Wellinghoff, FERC v. EPSA and Adjacent State Regulation of Customer Energy Resources, 40 HARV. ENVTL. L. REV. F. 23 (2016).
} 
sis. ${ }^{85}$ She draws upon examples from New York's ongoing Reforming the Energy Vision proceeding. ${ }^{86}$ Professor Michael Wara's Fostering Competition in the 21st Century Electricity Industry considers the potential of the Department of Justice's Horizontal Merger Guidelines in facilitating energy innovation and the development of robust and fair markets for energy services. $^{87}$

Finally, Professor Sharon B. Jacobs's Energy Deference analyzes EPSA's second question presented: whether the price FERC set for demand response in wholesale markets was arbitrary and capricious. ${ }^{88}$ Jacobs frames the Court's analysis within the burgeoning administrative law literature on deference to agency actions. She argues that EPSA is faithful to an approach of "super deference" because it relies on "deference proxies": the procedural safeguards employed by the agency, the presence or absence of expert opinions sanctioning the agency's choice, or even the presence or absence of a dissenting agency decisionmaker. ${ }^{89}$

\footnotetext{
${ }^{85}$ Denise A. Grab, Balancing on the Grid Edge: Regulating for Economic Efficiency in the Wake of FERC v. EPSA, 40 HARV. ENVTL. L. REV. F. 32 (2016).

${ }^{86} \mathrm{Id}$. at 38 .

${ }^{87}$ Michael Wara, Fostering Competition in the 21st Century Electricity Industry, 40 HARV. ENVTL. L. REV. F. 41 (2016).

${ }^{88}$ Sharon B. Jacobs, Energy Deference, 40 HARV. EnVTL. L. REV. F. 49 (2016).

${ }^{89} \mathrm{Id}$. at $55-56$.
} 